\title{
C.I.F. OfFice Activities
}

Our theme song around the office lately has been, "Oh where, oh where has that man moved to now?', as each mail produces more letters stamped, "Moved, address unknown". Not only are Foresters the most nomadic people on the face of the earth, but also the most forgetful. We therefore request that when you move, please try to remember to notify us early, so that we do not have to waste our time and your money on wrongly addressed mail.

Since March we have prepared and sent out three separate mailings including Imperial Life insurance premium notices to 500 participating members. Early in April all Active members received an election ballot, a copy of the new C.I.F. By-Laws and a notice from Lufthansa German Airlines regarding the European Tour. All other members received the By-Laws and the Lufthansa notice. Later in April with the help of the new Addressograph machine and an improved set of forms we managed to prepare and mail the dues notices to all members in record time, without hiring supplementary personnel.

In the past few months the Annual Meetings of the Champlain, North Western Ontario, Lake of the Woods and Ottawa Valley Sections were attended by the Secretary-Manager and found to be extremely worthwhile. Also attended was a regular meeting of the Orleans Section and an Executive meeting of the Manitoba Section, making a total of 7 sections visited since December.

Plans for two much improved European Study Tours are progressing favourably in cooperation with the Connecticut River Watershed Council Inc, with the advantage to C.I.F. of definite departure regardless of how many C.I.F. members make the trip. This will be a terrific opportunity for members to view European forestry at close range, while at the same time meet a group of our American counterparts and share their reactions to what is seen. To date about fifteen inquiries have been received by this office, and we urge you to return your tear sheets early if you are interested in the trip. (Please see ad in this issue.)

As mentioned earlier, the Election Ballots were mailed to Active members in mid-April and to date the percentage returned has been extremely low. It is rather disheartening to observe that not only do the majority of members fail to take enough interest in the Institute to nominate more than one candidate for each office, but they are also very negligent when it comes to registering their approval of the candidates who are nominated. Should enough ballots be received by June 30 to warrant asking a few local members to take the afternoon off to be scrutineers, the election results and statistics will be published in the September Chronicle.

The C.I.F. Annual Meeting to be held in Toronto October 5 to 8 is fast approaching, and the word is out that the Southern Ontario Section plans to set a precedent of excellence for future Annual Meetings. All members planning to attend the Meeting are urged to bring their wives in order to keep peace in the family. We understand that one of the airlines recently introduced a special half-fare rate for wives accompanying their husbands to Annual Meetings. Anticipating some valuable testimonials, the publicity department of 
the airline sent out letters to all wives of businessmen who used the special rates, asking how they enjoyed the trip. Responses are still pouring in asking, "What trip?".

D. M. IRVINE

\section{NEWS OF THE SECTIONS}

\section{Nova Scotia}

Mr. E. S. Telfer, has accepted a position with Bowaters Mersey Paper Company as Forester.

R. H. "Ron" Day of the Department of Lands and Forests, Truro, N.S., was recently appointed Secretary-Treasurer of the Nova Scotia Section, C.I.F. He replaces F. V. "Vince" Clark of Scott Paper Company, Truro, who has been Secretary-Treasurer since the founding of the Section ten years ago. Vince has contributed much to the Section in that time and the successful programs and annual meetings have been the result of his hard work. Vince acted as Secretary-Treasurer for the committee in charge of the 1963 C.I.F. Annual Meeting in Halifax, playing a big part in the success of that event.

A contract for aerial photography covering the counties of Halifax, Hants, Cumberland and Colchester consisting of approximately 6,600 square miles has been awarded to Capital Air Services Limited of Ottawa. This work is the first stage in the re-inventory of the forest resources of the Province of Nova Scotia. The Government was requested to start this inventory work by the Forestry Section of the Voluntary Economic Planning.

Maritime

M. J. MacDonald

A short business meeting of our Section was held at the Lord Beaverbrook Hotel in Fredericton on April 15 with Mr. T. M. Pond in the chair.

Although the attendance was not to capacity it was considered satisfactory. A very interesting program was prepared for the members and guests including the graduating foresters of the University of New Brunswick Faculty of Forestry.

Following a luncheon at the Hotel the students of the graduating class were presented with Forestry Rings by Dean Ker who also delivered a very informative and enlightening talk to the group.

Guest speaker for the occasion was Rev. W. L. Randall who imparted a very instructive message on selling the profession.

The Royal (Byrne) Commission on Finance and Municipal Taxation is very much in the news locally and the recommendations on timberland taxation have aroused considerable interest among foresters.

Considered in the light of the overall objectives and methods proposed, the recommendations certainly have a strong appeal.

They will undoubtedly lower the average tax burden on timberlands and promote uniformity of assessment. They should have a very strong tendency to stabilize the taxation of woodlands. 